\title{
METHODOLOGICAL BASES OF CONCEPT FORMATION AND CHOICE OF INNOVATIVE BUSINESS STRATEGIES
}

\author{
Vyacheslav Dzhedzhula', Iryna Yepifanova² \\ Vinnytsia National Technical University, Ukraine
}

\begin{abstract}
Modern economic world tendencies and practice of the developed countries testify that in the conditions of the high level of financial risks and influence of various crisis factors, one of the main problems of operation of enterprises is to ensure sustainable development. In such conditions, the innovative activity is the basis for ensuring the competitiveness of domestic enterprises and provision of sustainable development. Effective implementation of innovation activities involves the introduction of strategic management. An enterprise, which is a part of the external environment, must be able to adapt to existing and possible changes in the external environment to ensure effective activity. Success can be achieved not by those enterprises that are capable of forming a successful strategy, but those capable of adapting it in time to changes. In this regard, the issues of strategic management of innovation activity are very relevant for domestic enterprises. The question of the analysis of strategic management effectiveness is presented by I. Ansoff, Michael E. Porter, by Robert S. Kaplan, by David P. Norton. Issues related to the strategic management of innovation activities are studied by such scholars as S.M. Ilyashenko, N.M. Poliova, V.O. Shpyliova, I.L. Fedulova, T.M. Yankovets and others. The aim of the work is to improve the methodological bases for the formation of concepts and choice of innovative business strategies. Methodology. On the basis of the retrospective analysis, synthesis, and generalization, the existing methodological bases of the formation of concepts and choice of innovative strategies of enterprises are systematized and improved. The results of the study show that the innovative strategy is a certain interrelated sequence of actions to ensure the effective innovation of the enterprise in the light of the general strategy in the conditions of resource limitation and the impact of the external environment. It is established that the perspective direction of activation of the innovative strategy is the introduction of strategic maps and the system of balanced indicators. The practical implementation. It is reasonable to introduce one of the stages of the formation of an innovative strategy for drawing up a strategic map that will take into account different variants of the course of innovation activity and can serve as a basis for the formation and adjustment of the following innovative strategies of industrial enterprises. Value/originality. The inclusion of the strategic map to the stages of formation of innovative strategy will increase the efficiency of the financial support of innovation activity, as the management of the enterprise will work out a plan of action under different conditions of the course of innovation activity. In addition, an innovative strategy, especially in terms of financial support for innovation, must be integrated into a system of Balanced Scorecard of the enterprise.
\end{abstract}

Key words: strategic map, innovative strategy, strategy, innovation activity, Balanced Scorecard.

JEL Classification: 012, O32, B40

\section{Introduction}

Effective implementation of innovation activities involves the introduction of strategic management, which, in the opinion of several scientists, is an activity to achieve the important long-term goals of the system in the environment that is constantly changing, by changing the state of the system itself (Ansoff, 1979). The enterprise and the external environment are the main elements of strategic management. An enterprise, which is a part of the external environment, should be able to adapt to existing and possible changes in the external environment to ensure effective activity. The external environment, which is a dynamic system, is characterized by constant changes. An enterprise as a component of this system must always respond promptly to such changes. That is why not companies that are able to form a successful strategy, but those that can adapt it in time to change, can succeed. In this

Corresponding author:

${ }^{1}$ Department of Finance and Innovation Management, Vinnytsia National Technical University.

E-mail: djedjulavv@gmail.com

${ }^{2}$ Department of Finance and Innovation Management, Vinnytsia National Technical University.

E-mail: epifanovairene@gmail.com 
regard, the issues of strategic management of innovation activity are very relevant for domestic enterprises.

The question of the analysis of the effectiveness of strategic management has been presented by I. Ansoff (1979), Michael E. Porter (2008), Robert S. Kaplan and David P. Norton (1992). Issues related to the strategic management of innovation activities are addressed by such scholars as S.M. Ilyashenko (2010), I.L. Fedulova (2008), T.M. Yankovets (2010) and others.

The aim of the work is to improve the methodological foundations for the formation of concepts and the choice of innovative business strategies.

\section{The essence of the innovation strategy}

Over the past 50 years of the twentieth century, there is a process of evolution of approaches to management and planning as one of its elements: 50s - purely management decisions, 60s - long-term internal corporate planning, 70s - strategic planning, 80 s - strategic management, 90 s - research of strategic processes (Ilyashenko, 2010).

The classical approach to the choice of strategies is presented in the works of I. Ansoff (1979), according to whom the strategy is a set of rules for decision-making, which the organization guides in its activities.

According to Michael E. Porter (2008), the strategy is a creation of a unique and beneficial position that involves a certain set of activities. If there was only one perfect position, there would be no need for a strategy. This set provides a detailed analysis of conditions of the enterprise management taking into account the external environment. It is precisely the view of D.E. Korzenkov (2011), who states that strategic management involves the feedback between its stages for possible refinement, the modifying of the results of the previous stages; not only the process of developing, adapting, and implementing a strategy but also the processes of evolution and transformation of strategies depending on the change of the environment are especially important for success. Lack of feedback can lead to a negative progression of the most successful strategy. This is due to the fact that the environment, in which the enterprises operate, is quite variable and quite often any strategy involves making a number of adjustments.

Approaches to management have undergone a certain evolution and, in modern conditions, they are characterized by the following features (Ilyashenko, 2010):

- enterprises must constantly modify their competitive advantage if they seek to retain the position of a market leader;

- it is necessary to deviate from logically rational trivial decisions, as they are easily predicted by competitors, non-traditional decisions are necessary;

- the strategy, in principle, should be short-term, as the conditions of management are changing rapidly and these trends are increasing, requiring a constant review of strategic decisions.
Robert S. Kaplan and David P. Norton (2004) point out that in $70 \%$ of the enterprise there are problems that are not associated with a bad strategy, but with a failure to implement it. That is why not only the formation process but also the management of the strategy implementation, is very important.

Of particular importance is strategic management for innovation, which determines the formation of an innovation strategy, which is a part of the general strategy of the enterprise.

There are different approaches to determining the essence of innovation strategy. According to I.V.Fedulova (2008), the innovation strategy is a systemic concept that links and directs the development of the innovation activity of the subject of the economy with the system of long-term goals of innovation activity, as well as the method (choice of the most effective ways) for achieving and implementing the target innovative level of development, which includes the nature of resource allocation between alternative paths of innovation development and a type of behaviour.

Innovation strategy is also considered as the leading functional strategy of a high-tech industrial enterprise, which involves the formation of a complex of measures for technological improvement of production, changes in the organizational structure of the enterprise, the introduction of modern management technologies (Poreckova, 2013).

According to T.M. Yankovets (2010), an innovative strategy is any new means of achieving the strategic goal of the enterprise, whereas according to S. M. Iliashenko (2010), it is as an interconnected set of actions for ensuring the conditions of long-term survival and development of the enterprise in the market on the basis of creation and introduction of innovations. A similar view is maintained by N.M. Poliova and V.O. Shpyliova (2009), who believe that the strategy of innovation activity in the enterprise includes a number of interrelated elements and procedures: the definition of goals and objectives, the formation of priorities of innovation and the development of an optimal portfolio of innovations that are of paramount importance for successful business activity, as well as the assessment and analysis of the impact of innovations on the prospects for enterprise development. Antonyuk L.L., Poruchnik A.M., Savchuk V.S. (2003) determine the innovation strategy as a complex of actions.

In terms of a systematic approach, the innovation strategy is considered as one of the components of an economic strategy, defined as a set of rules, methods, and tools for finding the best prospective organizations for the development of scientific and technical research, resource policy (Makedon, Rubec, 2013; Vergal, 2011).

Therefore, in general, an innovative strategy has a certain interrelated sequence of actions to ensure the effective innovation of the enterprise in the light of the general strategy in the conditions of resource limitation and the impact of the environment. 
Strategies of the enterprise can be numerous but all of them are based on strategic alternatives (Makedon, Rubec, 2013; Vergal, 2011): the limited growth of the enterprise; growth; reduction. It is clear that the strategy of innovation can be based only on the first two alternatives. In general, the innovation strategy is quite similar to the general strategy of the enterprise and involves either strengthening the position of the company in the selected segment of the market in a particular industry or active diversification of activities. The fundamental difference between general and innovative strategies is that the innovation strategy has an element of novelty as a compulsory element.

\section{Types of innovative strategies}

Different numbers of innovative strategies are distinguished in the literature (Figure 1). Classically innovative strategies of the enterprise are divided into active (offensive, expansive) and passive (protective, defensive) (Twiss, 1992; Michael E. Porter, 2008; Antonyuk, Poruchnik, Savchuk, 2003). Among management levels, certain authors (Santo, 1990) distinguish passive, offensive and stagnant innovative strategies.

According to T.M. Yankovets (2012), it is reasonable to allocate six types of innovative strategies: traditional, opportunistic ("niche" strategy), simulative, defensive (protective), dependent, offensive. L. Vodachek and O. Vodachkova (1989) provide a similar classification of strategies.

They distinguish four main types of innovative strategy: actively offensive, moderately offensive, protective, and residual. A.I. Bogdanov (1991) considers intensely offensive, moderately offensive, protective and licensing (absorbing) strategies of innovation activity.

A.M. Batkovsky and A.P. Merzlyakova (2011) distinguish three main groups of innovation strategies: strategies for the implementation of research and development, introduction of innovations and strategy of mass production of previously created innovation products.

Thus, the authors share strategies depending on the product lifecycle and the state of the enterprise. This is due to the fact that at various stages of development and for different financial status, enterprises pursue different strategic goals. In general, most classical innovation strategies are similar, but they have different names from different authors.

Depending on the type of innovation, A.Y. Yudanov (1998) divides innovative strategies into violent (force), patient (niche), commutant (adaptation strategy) and exploratory (pioneer). The violent strategy is a strategy of competition, which is based on a reduction in production costs, which is achieved through the mass production of relatively inexpensive but quite good products. The patient strategy is to produce a limited number of highly specialized high-quality products with its ability to win more powerful competitors not by the force but by the ability of the firm.

Commutant strategy involves the most flexible satisfaction of small (local) market needs, and exploratory strategy is focused on radical innovations.

Certain authors categorize innovative strategies depending on the level at which they are planned. In particular, A. Thompson and A. Strickland (1993) distinguish four levels of strategy for diverse organizations: corporate, business strategy, functional and operational strategies, and for single-profile companies - business strategy, functional and operational strategies.

Ellen Chaffee (1985) identifies three distinct strategy models depending on the level and goals of the management: linear, adaptive, and interpretive.

In the author's view, the linear strategy, according to a linear model, which is directly focused on planning, is based on the fact that all enterprises have certain goals that must be achieved at the appropriate levels of management over a certain period of time. This strategy is based on the assumption that future operating conditions will be fairly stable or predictable.

The adaptive strategy, which is based on an adaptive model, implies that an enterprise should adapt to the identified changes in the process of evaluating the external and internal environment. In this case, the strategy means the development of opportunities and resources that allow the use of potential opportunities.

The interpretive strategy is based on an interpretive model that sees the strategy as something that emerges from a continuous dialogue between different perspectives outside the organization, which is a symbolic expression of a culture of an organization that depends on internal and external relations. This strategy is based on the formation of a potential positive attitude towards the company's activities and involves increasing the positive image.

To the main tasks of the innovation strategy, S.M. Iliashenko (2010) includes:

- efficient allocation and use of available resources and opportunities for development based on innovation and innovation activity (innovative development potential); - adaptation to changes of conditions of the external environment by finding new ways and areas of implementation of the company's potential, bringing the internal development opportunities into external, generated by the market.

I. Ansoff (1979) distinguishes four groups of rules, which define directions for action when defining a strategy:

1) the rules that are used to assess the firm's performance now and in the future;

2 ) the rules, under which the firm's relations with its environment are formed. They determine which types of products and technologies the firm will develop, how 


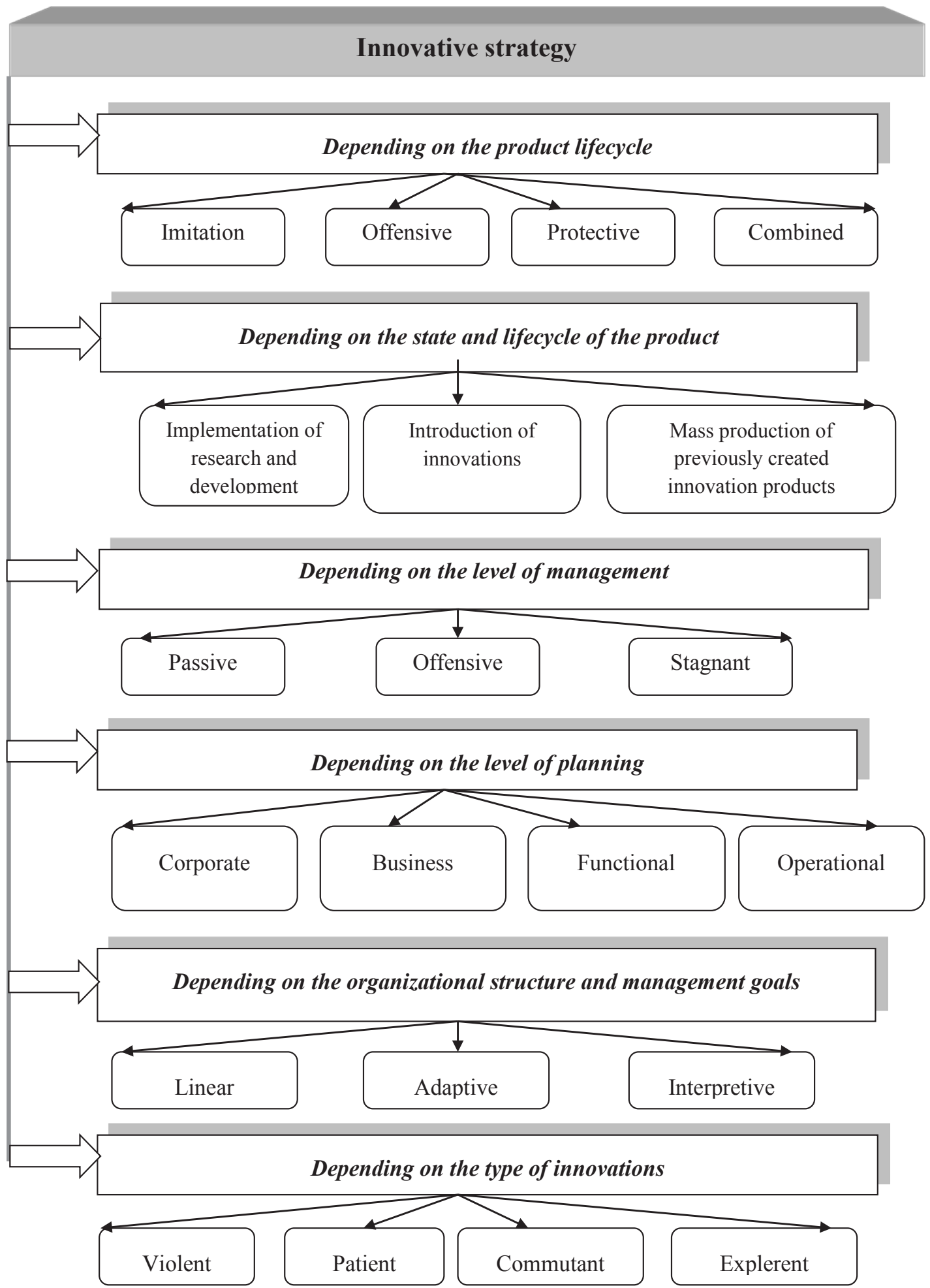

Figure 1. Systematized types of innovation strategies of enterprises

they will outperform their competitors. These rules are called product-market strategies;

3 ) the rules, according to which the relations and procedures within the firm are established;

4) the rules, by which the firm carries out operational activities.

\section{Features of strategic management of innovation activities}

In order to manage effectively the innovation activity of the enterprise, a staged approach is offered in the literature (Poliova, Shpyliova, 2009). At the same time, depending on the production conditions and 
the peculiarities of a particular economic situation, the stages are proposed by the authors as separate, and in different combinations.

By systematizing existing approaches to the stages of implementing an innovative strategy, the following (Figure 2) can be distinguished:

- formation of goals and tasks of innovation activity;

- analysis of internal and external environment;

- formation of an innovative strategy of the enterprise;

- long-term innovative forecasting on the basis of roadmapping;

- determination of the necessary amount of resources for the innovative activity of the enterprise;

- control over the implementation of the innovative strategy and its adjustment if necessary;

- definition of the influence of the innovative strategy on the economic development of the enterprise.

N. Poliova, V.A. Shpyliova (2009) complete strategic planning stages with the development of strategic plans, but in our opinion, taking into account the importance of the direct process of implementation of the innovation strategy, it is more expedient to include such a stage as the monitoring of the implementation of the innovation strategy and adjustment if it is necessary.

The primary task in the process of forming an innovation strategy is to determine the goals and tasks of innovation activity.

For each enterprise, it is necessary to formulate an individual strategy. The choice of strategy depends first and foremost on the level of product innovation, on the kind of innovation that the enterprise introduces.

At the same time, regardless of the level of innovation of products, enterprises should strive for further development, because "...the company achieves competitive advantages thanks to the innovation, it can only keep them with constant improvements. Competitors will immediately and necessarily overtake any company that will stop the improvement and implementation of innovations" (Michael E. Porter, 2008).

The factor such as the company's position with respect to the leading enterprises in a particular industry is also quite important. It is these parameters that will determine the goals and objectives of the enterprise's innovation activities.

A rather important stage in the formation of an innovative strategy is the analysis of environmental factors and the analysis of internal potential and threats that affect the implementation of the innovative strategy and activities of the enterprise as a whole.

In general, the choice of innovative strategies is carried out taking into account different methods, which in general form has matrices, indices, diagrams, polygons. The matrices of Ansoff, Boston Consulting Group, McKinsey General Electric, SWOT Analysis, and Balanced Scorecard are the main criteria for choosing business development strategies today. At the same time, the model of SWOT analysis is the most widely used, the benefits of the application of which are simultaneous consideration of external and internal factors of development. In addition, the model allows, based on the study of the enterprise's strengths and weaknesses, taking into account the influence of the environment, to determine the strategic directions for further development, as well as possible threats.

\section{Strategic maps in innovation activities}

The US companies at the present stage of development are actively using such a method of planning and forecasting activities as strategic maps or roadmapping, which in translation from English means traffic on the roadmap. Roadmapping involves the construction of so-called "roadmapping", i.e. the routes of the company's future development in the main areas of activity, such as market, products, technologies, competitors, raw materials, etc. In this case, its main dominant is the introduction of innovations, innovative technologies (Dissel, 2010).

Today, in the literature, you can find the concept of "roadmap", "strategic map" and roadmapping, which in essence are synonymous. According to Robert S. Kaplan and David P. Norton (2004), a strategic map is an applied image of a strategy that, on one sheet of paper, tells how integrated and combined enterprises are transformed into a single strategy and contain the indicators, by which it can be implemented. Consequently, this definition is entirely consistent with the understanding of the roadmap in (Dissel M., 2010; Phaal R., 2010; Alan F. Blackwell, Rob Phaal, Martin Eppler, Nathan Crilly, 2008).

Roadmapping technology was developed by Motorola in the 1970 s to maintain improved alignment between technology and the development of a new product, providing a structured visual description of the strategy (Phaal R., 2010).

However, a study by Alan F. Blackwell, R. Phaal, Martin Eppler, Nathan Crilly (2008) has shown that since the result of the roadmap is the presentation of the strategy as a schematic appendix, today there is a significant number of options for constructing roadmaps, that is, there are no coherent sets of visual customs and rules. The authors propose different templates of roadmaps and for innovation activity, the templates, which contain various components: market, product, technology, and results or innovation, personnel, technology.

The stages of building a strategic map correspond to the corresponding stages of the strategy and are closely interlinked, that is why it is reasonable to integrate them into the stages of formation of an innovative strategy to avoid duplication of action.

The peculiarity and benefit of a strategic map is the use of a framework that is structured in time (and often graphic) for the design, presentation, and transfer of strategic plans in terms of the evolution and development of technology, products, and markets. 


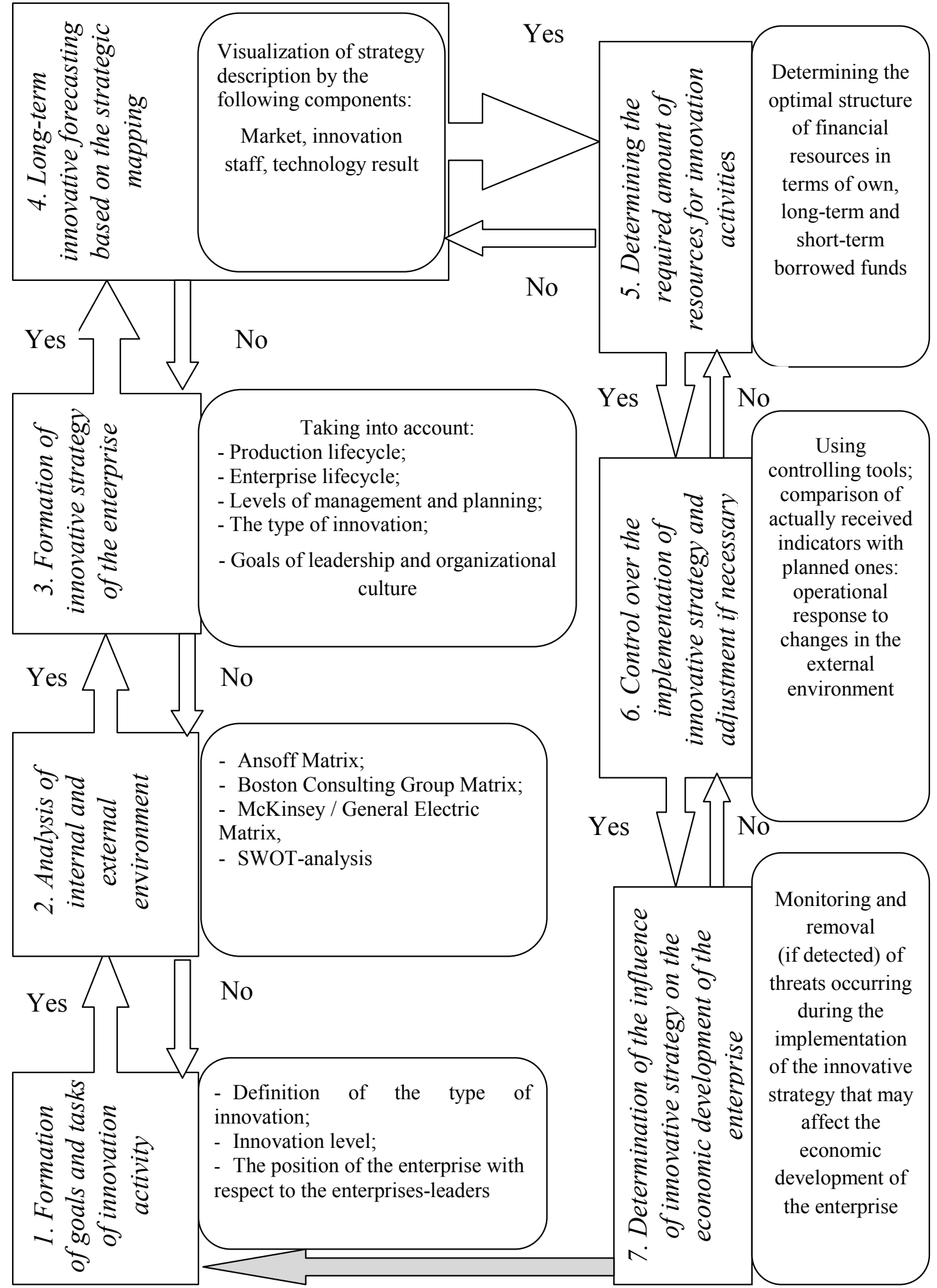

Figure 2. Stages of implementing an innovative strategy

In this regard, roadmapping technology is also closely related to other graphical planning approaches such as PERT (Program Evaluation and Review Technique) and Gantt Planning Tools (Robert Phaal, Clare J.P. Farrukh, David R. Probert, 2004).
One of the greatest benefits of this method is communication through functional and organizational boundaries. The process of developing strategic maps brings together and coordinates the various key stakeholders and perspectives. In addition, a well- 
developed roadmap can further expand and serve as a basis for further action. That is why it is very important to include an innovative strategy in the process of forming.

The integral structure of the strategic map is directly related to the fundamental issues that appear in any strategic context: Where do we want to go? Where are we now? How can we get there? Why should we act? What should we do? How should we do it? When?

In general, strategic maps are classified according to three criteria: purpose, format, and type ((Dissel M., 2010: Phaal R., 2010; Alan F. Blackwell, Rob Phaal, Martin Eppler, Nathan Crilly, 2008; Robert Phaal, Clare J.P. Farrukh, David R. Probert, 2004) (Table 1).

The essence of the model of strategic maps is to organize the control over the implementation of the established indicators and adjust the dynamics of the most significant for the implementation of the strategy of them. At the present stage, the formation of strategic maps is associated with a system of balanced indicators. Accordingly, strategic maps for innovation activities include the use of a system of indicators, which should be coordinated with the stages of innovation activities, sources of funding.

The study of works related to the formation of a system of Balanced Scorecard has shown that the peculiarities of their use are:

- the use of non-financial indicators along with financial ones;

- the Balanced Scorecard, which is carried out in four groups: finance, clients, internal processes, training, and development;

- this Balanced Scorecard provides an assessment of the effectiveness of the enterprise in the past and in the future;

- there is a connection between the indicators in the system, which is reflected in the strategic maps;

Table 1

Classification of strategic maps

\begin{tabular}{|c|c|}
\hline Name & Essence \\
\hline \multicolumn{2}{|r|}{ 1. Depending on the goal of creation } \\
\hline Product planning & The most common type of planning related to product technology. \\
\hline Service/planning capability & $\begin{array}{l}\text { The roadmap that focuses on organizational capacity as a bridge between technology and business. It is used } \\
\text { by service providers. }\end{array}$ \\
\hline Strategic planning & $\begin{array}{l}\text { The roadmap that focuses on developing a vision for a future business from the point of view of markets, } \\
\text { businesses, products, technologies, skills, culture, etc. }\end{array}$ \\
\hline Long-term planning & This type is used to maintain long-term planning, extending the planning horizon. \\
\hline $\begin{array}{l}\text { Planning an intellectual asset } \\
\text { (personnel) }\end{array}$ & $\begin{array}{l}\text { This type aligns the management of intellectual assets and knowledge management initiatives with business } \\
\text { objectives. }\end{array}$ \\
\hline Program planning & $\begin{array}{l}\text { This type of strategy focuses on the implementation of the strategy and relates primarily to the planning of } \\
\text { the project (for example, R \& D programs). }\end{array}$ \\
\hline Process planning & Planning a specific component of the process (for example, developing a new product). \\
\hline Integrated planning & $\begin{array}{l}\text { This type focuses on integrating and/or evolving technology from the point of view of how different technologies } \\
\text { are integrated into products and systems or from the point of view of the formation of new technologies. }\end{array}$ \\
\hline \multicolumn{2}{|r|}{ 2. Depending on the type } \\
\hline Industry & Formation of the strategy for the development of a particular industry, market, part of the industry. \\
\hline Corporate & Formation of development strategy at macro levels (individual corporate structures). \\
\hline Product & $\begin{array}{l}\text { Formulation of the product development strategy (product line) in time through market analysis, product } \\
\text { evaluation, and technology learning. }\end{array}$ \\
\hline Technological & Formation of technology development strategy, including high technology sector. \\
\hline Scientific, research & $\begin{array}{l}\text { Formation of a development strategy based on the selection of emerging technologies, taking into account } \\
\text { the increased attention to competences and research }\end{array}$ \\
\hline Program & $\begin{array}{l}\text { Formation of the development strategy at micro, macro, and meso levels to identify the impact of possible } \\
\text { problems on the development of programs and strategies. }\end{array}$ \\
\hline \multicolumn{2}{|r|}{ 3. Depending on the graphics format } \\
\hline Multilevel & The most common format that includes several levels (and sublevels) such as technology, product, and market. \\
\hline Column & $\begin{array}{l}\text { A roadmap in the form of a number of columns for each level or sub-level that simplifies and integrates the } \\
\text { necessary conclusions, simplifies the transfer, integration of roadmaps. }\end{array}$ \\
\hline Tables & $\begin{array}{l}\text { A roadmap or its certain levels in the form of tables (time in comparison with performance or requirements). } \\
\text { It is especially suitable for situations where performance can be quantified. }\end{array}$ \\
\hline Charts & $\begin{array}{l}\text { A roadmap is expressed as a simple graph or the graph, usually one for each sublevel, which is closely related } \\
\text { to the technological S-curves. }\end{array}$ \\
\hline Graphic representations & Some roadmaps use more creative graphical representations of transfer of technological integration and plans. \\
\hline Flow-charts & A certain type of graphical representation is a flowchart that is used to link goals, actions, and results. \\
\hline Mono level & $\begin{array}{l}\text { A roadmap that focuses on a single level roadmap. The disadvantage of this type is that there is usually no link } \\
\text { between levels. }\end{array}$ \\
\hline
\end{tabular}


- the system of Balanced Scorecard is implemented from the top to the bottom, through the whole enterprise; for each unit, a certain set of balanced indicators is formed; - the system of Balanced Scorecard usually contains no more than 20-25 indicators per enterprise, for a unit of about 7-10, for one employee no more than 5 .

Since innovation activity is subordinate to the operational one, it is very important to determine the impact of the innovative strategy on the economic development of the enterprise and, if necessary, to adjust a certain stage of the innovative strategy.

It would be very useful for domestic enterprises to introduce this approach in their economic activity since it creates opportunities for forming various directions of development of innovation activity, depending on the course of circumstances.

Financial managers of an enterprise must always have several optionsforimplementing an innovation strategyfrom the most optimistic to the pessimistic and timely adjust its implementation in accordance with external conditions. Today in Ukraine, there is a rather low share of innovative enterprises, and the proportion of those actively using strategic innovation planning is even less.

Thus, the introduction of a roadmap to the process of forming an innovation strategy will help increase its flexibility and ability to respond more quickly to changes in the external and internal environment of the enterprise.

At the same time, it is inappropriate for enterprises to use the benchmarking method, which promotes universalization, and not individuality. This is the opinion of Michael E. Porter (2008), who points out that the more companies engage in benchmarking, the more similar they become, and the competition becomes a competition of identical ways, and none of the enterprises is capable of defeating.
The formation of strategy and the development of strategic maps, the system of balanced indicators allows determining the necessary amount of resources for the innovative activity of the enterprise. At the same time, the company can form several options for funding innovative activities in terms of economic development options and the type of projected innovations.

The process of monitoring the implementation of the innovation strategy and adjusting as necessary is no less important.

\section{Conclusions}

Consequently, on the basis of systematization of modern approaches to the essence of innovation strategy, it has been determined that it has a certain interrelated sequence of actions to ensure the effective innovation of the enterprise in the light of the general strategy in the conditions of resource limitation and the impact of the external environment.

It has been established that the perspective direction of activation of the innovation strategy is the introduction of strategic maps and a system of balanced indicators. In this regard, one of the stages of the formation of an innovative strategy is the drawing up of a strategic map that takes into account different variants of the course of innovation activity and can serve as a basis for the formation and adjustment of the following innovative strategies of industrial enterprises. The inclusion of this component in the stages of the formation of an innovation strategy will increase the efficiency of using the financial support of innovation activity, as the enterprise management will form a plan of action under different conditions of the course of innovation activity. In addition, an innovative strategy, especially in terms of financial support for innovation, must be integrated into a system of balanced indicators of the enterprise.

\section{References:}

Ansoff I. (1989). Strategicheskoe upravlenie [Strategic management]. Moscow: Economics. (in Russian)

Antonyuk L.L., Poruchnik A.M. and Savchuk V.S. (2003). Innovacii: teorija, mehanizm rozrobky ta komercializacii [Innovation: theory, mechanism of development and commercialization]. Kyiv: KNEU. (in Ukrainian)

Batkovsky A.M. and Merzlyakova A.P. (2011). Ocenka innovacionnyh strategij predprijati [Assessment of enterprise innovation strategies]. Voprosy innovacionnoj jekonomiki, No 7(7), pp. 10-17. Retrieved from: http://www.creativeconomy.ru/articles/14558/ (Accessed 20 May, 2018)

Blackwell Alan F., Phaal Rob, Eppler Martin and Crilly Nathan Strategy Roadmaps: New Forms, New Practices. Diagrammatic Representation and Inference. Vol. 5223 of the series Lecture Notes in Computer Science, pp. 127-140.

Bogdanov A.I. (1991). Strategicheskoe upravlenie nauchno-tehnicheskim progressom na predprijatii [Strategic management of scientific and technological progress at the enterprise]. Moscow: VAF. (in Russian)

Chaffee E. Three models of strategy. Academy of Management Review, vol. 10, № 1.

Dissel M. (2010). Value roadmapping. Research Technology Management. № 6, pp. 28-30.

Fedulova I.L. (2008). Konceptualni zasady ekonomiky znan [Conceptual foundations of the knowledge economy]. Ekonomichna teorija, № 2, pp. 37-59.

Ilyashenko S.M. (2010). Strategichne upravlinnja innovacijnoju dijalnistju pidpryjemstva na zasadah marketyngu innovacij [Strategic management of innovative activity of the enterprise on the bases of marketing of innovations]. Aktualni problemy ekonomiky, № 12, pp. 111-119.

Kaplan R.S. \& Norton D.P. (2004). Strategy Maps: Converting Intangible Assets into Tangible Outcomes. Boston: Harvard Business School Press. 
Korzenkov D.E. (2011). Osnovni vymogy do formuvannja systemy strategichnogo upravlinnja pidpryjemstvom [The main requirements for the formation of the system of strategic management of the enterprise] Akademichnyj ogljad, № 1(34), pp. 83-88.

Makedon V.V. \& Rubec D.S. (2013). Strategichnyj innovacijnyj rozvytok pidpryjemstv: teorija ta metodologija [Strategic Innovative Development of Enterprises: Theory and Methodology]. Visnyk NTU „HPI”. Serija: Tehnichnyj progres $i$ efektyvnist vyrobnyctva, № 45(1018), pp. 75-86.

Michael E. Porter (2008). On Competition: Updated and Expanded Edition. Harvard Business School Press.

Poliova N.M. \& Shpyliova V.O. (2009). Formuvannja mehanizmu upravlinnja innovacijnoju dijalnistju mashynobudivnyh pidpryjemstv [Formation of the mechanism of management of innovative activity of machinebuilding enterprises]. Aktualni problemy ekonomiky, № 4, pp. 130-134.

Phaal R., Farrukh Clare J.P. and Probert David R. (2004). Technology roadmapping - A planning framework for evolution and revolution. Technological Forecasting \& Social Change, № 71, pp. 5-26.

Phaal R. (2010). Roadmapping for strategy and innovation. University of Cambridge, Institute for Manufacturing, 2010. Retrieved from: http://www.ifm.eng.cam.ac.uk/uploads/Research/CTM/Roadmapping/roadmapping overview.pdf (Accessed 20 May, 2018)

Poreckova K.V. (2013). Klassifikacija innovacionnyh strategij promyshlennyh predprijatij [Classification of innovative strategies for industrial enterprises]. Sovremennye problemy nauki i obrazovanija (Electronic journal), № 2. Retrieved from: www.science-education.ru/108-9031 (Accessed 20 May, 2018)

Robert S. Kaplan \& David P. Norton (1992). The Balanced Scorecard - Measures That Drive Performance. Harvard business review, No 70(1), pp. 71-79.

Santo B. (1990). Innovation as a Means of Economic Development: trans. from Hungarian; ed. by B.V. Sazonov. Moscow: Progress. (in Russian)

Thompson Arthur A., Jr. \& Strickland III A.J. (1993). Strategic management: concepts \& cases. 7th ed. Burr Ridge, IL: Irwin.

Twiss B. (1992). Managing Technological Innovation. 4th Ed, Pitmans, London.

Vergal K.Ju. (2011). Teoretychni pidhody do klasyfikacii innovacijnyh strategij [Theoretical approaches to the classification of innovative strategies]. Teoretychni $i$ praktychni aspekty ekonomiky ta intelektualnoi vlasnosti, vol. 2, pp. 214-219.

Vodachek L. \& Vodachkova O. (1989). Strategija upravlenija innovacijami na predprijatii [Strategy of innovation management at the enterprise]. Moscow: Economics. (in Russian)

Yankovets T.M. (2010). Innovacijni strategii pidpryjemstva legkoi promyslovosti jak zasib realizacii jogo innovacijnogo potencialu [Innovative strategies of the light industry enterprise as a means of realizing its innovative potential]. Aktualni problemy ekonomiky, № 2, pp. 167-174.

Yankovets T.M. (2012). Realizacija innovacijnyh strategij dlja dosjagnennja konkurentnyh perevag [Realization of innovative strategies for achievement of competitive advantages]. Problemy nauky, № 12, pp. 33-40.

Yudanov A.Y. (1998). Konkurencija. Teorija i praktika [Competition. Theory and practice]. Moscow: GNOME PRESS. (in Russian) 